\title{
Evaluation of major constraints to revegetation of lead/zinc mine tailings using bioassay techniques
}

\author{
Z.H. Ye ${ }^{\text {a }}$, W.S. Shu ${ }^{\text {b }}$ Z.Q. Zhang ${ }^{\text {b }}$, C.Y. Lan ${ }^{\text {b }}$, M.H. Wong ${ }^{\mathrm{a}, *}$ \\ ${ }^{a}$ Department of Biology, Institute for Natural Resources and Environmental Management, Hong Kong Baptist University, \\ 224 Waterloo Road, Kowloon Tong, Hong Kong, China \\ b School of Life Science, Zhongshan University, Guangzhou 510275, China
}

Received 27 December 2000; received in revised form 13 December 2001; accepted 24 January 2002

\begin{abstract}
The residues from the extraction of lead/zinc $(\mathrm{Pb} / \mathrm{Zn})$ ores of most $\mathrm{Pb} / \mathrm{Zn}$ mines are permanently stored in tailings ponds, which require revegetation to reduce their environmental impact. This can only be done if the main constraints on plant establishment are evaluated. This can readily be done by field and greenhouse studies.

To test this, the properties of different tailings from Lechang $\mathrm{Pb} / \mathrm{Zn}$ mine located at the north of Guangdong Province in southern China have been studied. Physical and chemical properties including concentrations of metals $(\mathrm{Pb}, \mathrm{Zn}, \mathrm{Cd}$ and $\mathrm{Cu}$ ) in the tailings and soils collected from different sites have been measured. The results showed that tailings contain low nitrogen $(0.016-0.075 \%)$, low-organic matter $(0.58-1.78 \%)$, high salt $(3.55-13.85 \mathrm{dS} / \mathrm{m})$, and high total and diethylene-tetramine-pentaacetic acid (DTPA)-extractable metal concentrations (total: 1019-1642 $\mu \mathrm{g} \mathrm{g}^{-1} \mathrm{~Pb}, 3078-6773$ $\mu \mathrm{g} \mathrm{g}^{-1} \mathrm{Zn}, 8-23 \mu \mathrm{g} \mathrm{g}^{-1} \mathrm{Cd}$, and $85-192 \mu \mathrm{g} \mathrm{g}^{-1} \mathrm{Cu}$; DTPA-extractable: $59-178 \mu \mathrm{g} \mathrm{g}^{-1} \mathrm{~Pb}, 21-200 \mu \mathrm{g} \mathrm{g}^{-1} \mathrm{Zn}, 0.30-1.5$ $\mu \mathrm{g} \mathrm{g}^{-1} \mathrm{Cd}$, and $\left.4.3-12 \mu \mathrm{g} \mathrm{g}^{-1} \mathrm{Cu}\right)$. Aqueous extracts of tailings/soils $(10 \%, 20 \%$ and $30 \%$, w/v) from different sites were prepared for testing their effects on seed germination and root elongation of a vegetable crop Brassica chinensis and a grass species Cynodon dactylon. It was found that root elongation provided a better evaluation of toxicity than seed germination. The ranking of toxicity using root elongation was: high-sulfur tailings $>$ tailing dam $>$ sparsely vegetated tailings $>$ densely vegetated tailings $>$ mountain soil for both plants. This order was consistent with DTPA-extractable $\mathrm{Pb}$ contents in the tailings and soils. B. chinensis seedlings were then grown in the mixtures of different proportions of tailings and farm soil for 4 weeks, and the results (dry weights of seedlings) were in line with the root elongation test. All these demonstrated that heavy metal toxicity, especially available $\mathrm{Pb}$, low content of nutrient, and poor physical structure were major constraints on plant establishment and colonization on the $\mathrm{Pb} / \mathrm{Zn}$ mine tailings. () 2002 Published by Elsevier Science Ltd.
\end{abstract}

Keywords: $\mathrm{Pb} / \mathrm{Zn}$ mine; Toxicity; Root elongation; Yield; Brassica chinensis; Cynodon dactylon

\section{Introduction}

Apart from the aesthetic and economic problems associated with large areas of derelict land, tailings dumps can be important sources of water pollution and of wind-borne, metal-containing dusts (Freedman,

\footnotetext{
${ }^{*}$ Corresponding author. Tel.: +852-2339-7050; fax: +8522339-5995.

E-mail address: mhwong@hkbu.edu.hk (M.H. Wong).
}

1995). In the northern part of Guangdong Province, China, about 1700 thousand ha of farmland, which accounted for $7.3 \%$ of the total cultivated land in this area, are contaminated by heavy metals released from mining activities (Shu, 1997). Chemical and physical techniques are available for dust control and stabilization against water erosion, but the long-term objective of waste rehabilitation can only be realistically achieved by the use of vegetation as a basis for landscaping, stabilization and pollution control (Bradshaw and Johnson, 1992; Freedman, 1995). 
However, vegetation establishment on mine tailings is always difficult (Ernst, 1988; Johnson et al., 1994). In addition to the high level of acidity, $\mathrm{Pb} / \mathrm{Zn}$ mine tailings may also contain toxic concentrations of metals, such as $\mathrm{Pb}, \mathrm{Zn}$ and $\mathrm{Cd}$, low levels of major plant nutrients, poor physical structure, and excess salinity (Ernst, 1988; Bradshaw and Johnson, 1992; Shu, 1997). In addition, different mine wastes have different constraints for revegetation; the chemical composition can vary vertically and laterally in the same tailings pond (Shu, 1997). In order to successfully reclaim mine tailings, it is essential to assess the physical, chemical, and biological factors pertaining to mine wastes, in order to gain a full understanding of constraints and opportunities (Johnson et al., 1994). Day and Ludeke (1979) also indicated that since most mineral wastes are very low in plant nutrients, careful attention must be given to their correct fertilization prior to planting.

In China there are over 8000 national and 230000 private mining companies presently operating (Young, 1988), producing 60 million ton mining wastes annually (Shu, 1997). The Lechang $\mathrm{Pb} / \mathrm{Zn}$ Mine Operation (lat $24^{\circ} 40^{\prime} \mathrm{N}$, long $113^{\circ} 20^{\prime} \mathrm{E}$ ) is located in the $\mathrm{Pb} / \mathrm{Zn}$ mine zone in the north of Guangdong Province, southern China. The climate is sub-tropical and the annual rainfall is about $1500 \mathrm{~mm}$. The operation started in 1959 and is a conventional underground mining operation covering an area of $1.5 \mathrm{~km}^{2}$. It produces approximately 30000 ton of tailings annually with a dumping area of 60000 $\mathrm{m}^{2}$ (Ye et al., 2000). Most of the dumping area is bare and lacks vegetation cover.

The Lechang site was chosen for testing assessment techniques. Tailings toxicity and other major constrains for plant establishment were assessed by a seed germination/root elongation test and an early seedling growth test, using Brassica chinensis and Cynodon dactylon as test species. Smith (1991) reported that only three vascular plant toxicity tests developed by the USEPA are currently approved for laboratory use: (1) duckweed (Lemna) acute toxicity test; (2) seed germination/root elongation toxicity test; and (3) early seedling growth toxicity test. It has also been reported that root elongation test is a simple and sensitive technique for detecting toxicity of heavy metals (Wong and Bradshaw, 1982; Godbold, 1994). B. chinensis has a high-germination rate and fast root growth (Wong and Lau, 1983), whilst $C$. dactylon is one of the most common turf grasses in southern China (Ye et al., 2000).

\section{Materials and methods}

\subsection{Site description}

Four tailings sites (A, B, TD and $\mathrm{SH}$ ) at the Lechang $\mathrm{Pb} / \mathrm{Zn}$ mine area, one mountain site $(\mathrm{M})$ next to Site $\mathrm{B}$, and one clean site (OF) located at an organic farm in Hong Kong were selected.

Site A is a tailings disposal area, previously a pond close to a roadside, with a relatively high-plant cover, and a substantial amount of undecomposed leaf litter. Bidens bipinnata, Erigeron acer and Vitex negundo are the dominant species at this site. Some trees (e.g., Cinnamomum burmannii Cinnamomum camphora and Rhus chinensis) and shrubs (e.g., the dominant $V$. negundo) occur. Site B is a tailings pond of which the central portion is bare except for three small patches of $C$. dactylon. It has a slippery and reddish brown surface, with Imperta cylindrica and $R$. chinensis growing around the margin. Site TD is a tailings heap with black tailings on the sides of the heap, with a good growth of Bidens bipinnata. Site $\mathrm{M}$ is a mountain site with normal soil adjacent to Site B with a luxuriant growth of vegetation, and a high diversity of plant species, with many tree species, e.g. $R$. chinensis and Pinus massoniana. Site HS is an area of fresh tailings with a high-sulfur content, without any vegetation. Site OF is an area cultivating crops from an organic farm in Hong Kong.

\subsection{Sample collection and preparation}

Samples of tailings and soils were randomly collected from the selected sites in June 1995. The soil used for cultivating vegetable crops from the organic farm was used as a control and also as tailings ameliorant. Seeds of B. chinensis and C. dactylon were purchased from a local commercial seed store. The soils and tailings for the analysis of general properties were air-dried for 2 weeks and passed through 2-mm mesh sieve.

\subsection{Tailings and soil analysis}

Tailings and soil samples from Sites A, B, TD and $M$ were subject to physical and chemical analysis. $\mathrm{pH}$ (solid:distilled water $=1: 2$ ) was determined using a Beckman $\mathrm{pH}$ meter and electrical conductivity (EC; solid:distilled water $=1: 2$ ) using an Orion $160 \mathrm{EC}$ meter (Grimshaw, 1989). Total organic carbon (C) and total nitrogen $(\mathrm{N})$ contents were measured using a PE 2400, CHNS analyzer. Total phosphorus (P) was extracted by perchloric acid digestion, and then determined using the molybdenum blue method (Olsen and Sommers, 1982). Tailings/soil texture was analyzed using the hydrometer method (Allen et al., 1974). The total and diethylenetetramine-pentaacetic acid (DTPA)-extractable $\mathrm{Pb}, \mathrm{Zn}$, $\mathrm{Cd}$ and $\mathrm{Cu}$ contents were determined using flame atomic absorption spectrometry (AAS) after extraction with conc. $\mathrm{HNO}_{3}+$ conc. $\mathrm{HClO}_{4}, 5: 1$, v/v (Baker and Amacher, 1982) and DTPA [(1.976 g DTPA + $14.29 \mathrm{~g}$ triethanolamine $+1.47 \mathrm{~g} \mathrm{CaCl}_{2} \cdot 2 \mathrm{H}_{2} \mathrm{O}$ ) dissolved in 980 $\mathrm{ml}$ deionnized $\mathrm{H}_{2} \mathrm{O}$, and made up to $11, \mathrm{pH}$ 7.30] (Lindsay and Norvell, 1978) respectively. Tailings col- 
lected from Site HS and control soil collected from the organic farm were also analyzed for $\mathrm{pH}, \mathrm{EC}$, texture, total and DTPA-extractable contents of $\mathrm{Pb}, \mathrm{Zn}, \mathrm{Cd}$ and $\mathrm{Cu}$ using the methods described above.

\subsection{Toxicity tests}

\subsubsection{Seed germination and root elongation test}

Tailings from Sites A, B, TD and HS and soil from Site $\mathrm{M}$ were used for the toxicity test. Different concentrations of aqueous extracts $(10 \%, 20 \%, 30 \% \mathrm{w} / \mathrm{v})$ were prepared by blending the appropriate weight of tailings or soil samples in distilled water respectively with an electric shaker at $100 \mathrm{rpm}$ for $1 \mathrm{~h}$. The extracts were then filtered through a Whatman No. 42 filter paper. Values of $\mathrm{pH}$ and $\mathrm{EC}$, and $\mathrm{Pb}, \mathrm{Zn}, \mathrm{Cd}$ and $\mathrm{Cu}$ contents in the extracts were determined.

Twenty seeds of $B$. chinensis and $C$. dactylon were placed on alkathene beads in glass petri dishes (diameter: $12 \mathrm{~cm}$ ) respectively. Six $\mathrm{ml}$ of the appropriate extract was added to each petri dish, and $6 \mathrm{ml}$ of distilled water was used as a control treatment. There were three replicates for each treatment and species. The experiment was conducted under a $16-\mathrm{h}$ light $/ 8 \mathrm{~h}$ dark cycle at a temperature of $24 \pm 4{ }^{\circ} \mathrm{C}$ in a growth chamber. Treatments were augmented with $0.5 \mathrm{ml}$ of extract daily. The percentages of seed germination and root length of germinated seeds were recorded at days 4,7 and 14 (USEPA, 1992). $\mathrm{ECG}_{30}$, the effective concentration to reduce root growth (elongation) by $30 \%$, was also calculated according to the root elongation from seedlings grown in control and treatment extracts.

\subsubsection{Seedling growth test}

Tailings from Sites A, B, TD and HS and soil from Site $\mathrm{M}$ were used for the seedling growth test. Different proportions of tailings or soil $(10 \%, 25 \%, 50 \%$ and $100 \%$ $\mathrm{w} / \mathrm{w})$ were thoroughly mixed with the appropriate weight of farm soil from Site OF. Farm soil alone was used as control, and triplicate treatments were prepared. $\mathrm{pH}, \mathrm{EC}$, texture, total contents $\left(\mathrm{HNO}_{3}\right.$ and $\left.\mathrm{HClO}_{4}\right)$ and DTPA-extractable contents of $\mathrm{Pb}, \mathrm{Zn}, \mathrm{Cd}$ and $\mathrm{Cu}$ in the mixtures were determined using the methods described above.

Six seeds of B. chinensis were sown in each pot (diameter: $6 \mathrm{~cm}$, height: $7 \mathrm{~cm}$ ). The pots were arranged in a randomized block design and watered daily, and $25 \%$ Hoagland's solution (Hewitt, 1966) was added weekly. Pots were placed in a greenhouse, with temperature varying between 25 and $35^{\circ} \mathrm{C}$, for 4 weeks. At the end of the second week, three seedlings were thinned out and three healthiest seedlings were left.

Plants were harvested after 4 weeks. Roots were washed three times with deionized water to remove the associated soil particles. Plant tissues were dried to constant weight at $70{ }^{\circ} \mathrm{C}$ and the total dry weights were recorded.

\subsection{Statistical analysis}

The data were analyzed using a SPSS statistical package on an IBM personal computer (Little and Hills, 1978). One-way analysis of variance (ANOVA) was carried out to compare the means of different treatments. Where significant $\mathrm{F}$ values were obtained, differences between individual means were tested using Tukey-HSD tests at 0.05 significance level.

\section{Results and discussion}

\subsection{General properties of tailings and soils}

The general properties of tailings and soils are presented in Table 1. The $\mathrm{pH}$ values of tailings at Sites A, B, TD and HS were near neutral (pH 7.4, 6.5, 7.5 and 7.6, respectively). Comparing with the other sites within the Lechang mine, the $\mathrm{pH}$ of tailings at Site $\mathrm{B}$ was more variable, ranging from 2.8 to 7.9 . The soil collected from mountain site (M) and the organic farm (OF) were acidic ( $\mathrm{pH} 5.2$ and 4.8, respectively). $\mathrm{pH}$ values ranging between 5.8 and 9.0 were reported in four other $\mathrm{Pb} / \mathrm{Zn}$ mine tailings in southern China by Shu (1997). pH values of the soils at Sites M and OF fell within the range for normal red soils in southern China. Despite its known high-sulfur content, the $\mathrm{pH}$ of HS tailings was still high, probably because of its recent origin.

EC values of tailings collected from Sites A, B, TD and HS were 6.0, 7.7, 5.4 and $3.9 \mathrm{dS} / \mathrm{m}$, respectively, significantly higher than those of soils from Sites $\mathrm{M}$ and $\mathrm{OF}$. The highest $\mathrm{EC}$ value $(13.8 \mathrm{dS} / \mathrm{m})$ was found at one location in Site B, associated with poor growth of $C$. dactylon. Salinity is a common feature in tailings of high pyrite and carbonate content (Nielson and Peterson, 1972). At an EC of $4 \mathrm{dS} / \mathrm{m}$, yields of many crops will be restricted due to inhibition of plant growth and seed germination (Wild, 1993). High-salt levels may also adversely affect plant metabolism and/or membrane permeability (Greenway and Munnus, 1980). Therefore, salinity in the Lechang tailings may be one of the major constraints to vegetation establishment. The EC of HS tailings was low, perhaps again because of its recent origin.

Total N contents of the tailings from Sites TD, B and HS were significantly lower than those of soils from Sites $\mathrm{OF}$ and M. Soil from Site OF and tailings from Site TD contained the highest total $\mathrm{P}(0.51 \%$ and $0.44 \%$, respectively), more than twice that of the tailings at Site B $(0.18 \%)$. Total organic C contents of soils at Sites M and OF $(3.66 \%$ and $3.30 \%$, respectively) were significantly higher than those from tailings at Sites SH, B and TD 
$(0.35 \%, 0.58 \%$ and $0.75 \%$, respectively). For the growth of rice, soil with total $\mathrm{N}>0.2 \%$ was considered high, $0.1-0.2 \%$ moderate and $<0.1 \%$ low (Zhijiang Agricultural University, 1991). It was also reported that total $\mathrm{P}$ in soil below $0.08-0.1 \%$ would limit plant growth (Zhijiang Agricultural University, 1991). Therefore, N contents in the tailings of Sites A, B and TD were inadequate for plant growth (Table 1). The organic matter content as reflected by total organic $\mathrm{C}$ content, was lower in the tailings when compared with the surface horizons of most natural soil (usually $3-5 \%$ ), especially at Sites B, TD and HS. The higher N and total organic C contents of tailings in Site A compared to Sites B and TD may contribute to the greater plant diversity at the former site. Shu (1997) studied the floristic diversity in relation to soil characteristics at a $\mathrm{Pb} / \mathrm{Zn}$ mine complex in southern China, and found that the soil of the speciesrich area had a higher plant nutrient value than speciespoor area. The high-organic matter content in Site A was due to many fallen leaves. This can be a strategy by which plants exclude accumulated metals.

Tailings from Site A $(23.28 \%$ clay, $56.72 \%$ silt and $20.00 \%$ sand) and Site B $(9.72 \%$ clay, $51.00 \%$ silt and $39.28 \%$ sand) were silty loam. Tailings from Sites TD (7.72\% clay, $29.36 \%$ silt and $62.92 \%$ sand) and HS $(0.00 \%$ clay, $10.72 \%$ silt and $89.28 \%$ sand) (Table 1) were sandy loam. The HS tailings contained no clay fraction. The mountain soil was classified as a loamy soil $(26.28 \%$ clay, $26.44 \%$ silt and $47.28 \%$ sand).

The data presented in Table 1 show that organic matter, $\mathrm{N}$ content and physical structure of the tailings were poor for plant establishment. Nutrient deficiency is common in mine spoils (Smith and Bradshaw, 1979; Pichtel et al., 1994; Shu, 1997), making plant establishment difficult. Organic matter not only acts as a reservoir of essential macro-nutrients, but also provides a food resource for invertebrates and microorganisms that support the decay process and thus help nutrient recycling (Johnson et al., 1994). Low-organic matter may lead to leaching of nutrients, especially when water infiltration is rapid. Therefore, adding inorganic fertilizer alone to the mine spoils is inadequate. The use of organic matter can improve the physical structure (Ye et al., 1999).

Total and DTPA-extractable concentrations of $\mathrm{Pb}$, $\mathrm{Zn}, \mathrm{Cd}$ and $\mathrm{Cu}$ in the tailings are shown in Table 2, and the results were similar to those obtained from an abandoned $\mathrm{Pb} / \mathrm{Zn}$ tailings pond in New Mexico, USA (Sidle et al., 1991) and Shuikoushan $\mathrm{Pb} / \mathrm{Zn}$ mine tailings, Hunan, China (Shu, 1997). Total concentrations of Pb, $\mathrm{Zn}, \mathrm{Cd}$ and $\mathrm{Cu}$ in the tailings were much higher than in the soils of Sites M and OF. Total $\mathrm{Pb}$ concentration in Site A was the highest among the studied sites. However, DTPA-extractable $\mathrm{Pb}$ content was significantly lower at Site A than at the other tailings sites (HS, B and TD). DTPA-extractable $\mathrm{Pb}$ contents for the studied sites were 
in the following order: $\mathrm{HS}>\mathrm{TD}>\mathrm{B}>\mathrm{A}>\mathrm{M}>\mathrm{OF}$. Tailings from Sites A and TD contained the highest total and DTPA-extractable $\mathrm{Zn}$ and $\mathrm{Cd}$ concentrations. Tailings from Site A also contained the highest total and DTPA-extractable Cu. Soil collected from Site OF only contained $4.6 \mu \mathrm{gg}^{-1}$ total $\mathrm{Cu}$ which indicated this soil suffered from potential $\mathrm{Cu}$ deficiency (Table 2).

The relationship between growth of established plants and metal contents in tailings or soil might be complicated by the time available for growth since deposition of tailings in each area has ceased. Difference in the age of the tailings may have affected plant establishment. However, Site A with a dense plant cover, had higher contents of total $\mathrm{Pb}, \mathrm{Zn}, \mathrm{Cd}$ and $\mathrm{Cu}$, and extractable $\mathrm{Cd}$ and $\mathrm{Cu}$ than those of Site $\mathrm{B}$ with small patches of $C$. dactylon. The dense vegetation at Site A may be due to higher total organic $\mathrm{C}, \mathrm{N}$, and lower extractable $\mathrm{Pb}$ contents. It is commonly known that when organic matter and other mineral nutrients are in abundant supply, $\mathrm{Pb}$ toxicity does not occur (Woolhouse, 1983; Wild, 1988). Lead toxicity occurs most commonly on waste heaps from mining operations where organic matter and nutrient contents of the soil are low. The results presented here suggest that higher extractable $\mathrm{Pb}$, lower nutrients (especially $\mathrm{P}$ and $\mathrm{N}$ ) and organic $\mathrm{C}$ may be the main factors that affect plant growth on Site B. It has been indicated that high concentrations of toxic metals are the major cause of sparse vegetation cover of metalliferous mine waste and phosphorus concentrations are the immediate determinant, firstly because $\mathrm{P}$ is an important nutrient, and secondly it acts as a complexing agent for heavy metals and reduce their toxicity (Smith and Bradshaw, 1979).

\subsection{Toxicity tests}

\subsubsection{Seed germination and root elongation tests}

The results from the analysis of water extracts of tailings/soil show that dilution of the extracts $(10 \%$, $20 \%$, and $30 \%$, tailings (w)/water (v)) dramatically lowered the soluble salt content (EC values). However, dilution of extracts resulted in unchanged $\mathrm{pH}$ values. The results also show that the metal contents in water extracts of tailings were quite low, comparing with the DTPA-extractable portion (data not presented here). It has also been noted that only a small proportion of $\mathrm{Pb}$, $\mathrm{Zn}, \mathrm{Cd}$ and $\mathrm{Cu}$ in tailings could be extracted by water (Ye et al., 1999). However, heavy metals may inhibit root elongation and delay seed germination of a large variety of species even at very low concentrations (Wong and Bradshaw, 1982). For example, $0.1 \mu \mathrm{g} \mathrm{ml}^{-1} \mathrm{Zn}$ or $\mathrm{Cu}$ in nutrient solution could significantly reduce growth (fresh weight of whole seedling) of Sinapis alba (DeKock, 1956). The present results here showed that tailings from the tailings heap (TD) and high-sulfur tailings (HS) contained higher water-soluble $\mathrm{Pb}(0.18$ 
and $0.33 \mu \mathrm{g} \mathrm{ml}^{-1} \mathrm{~Pb}$ in extracts of $30 \% \mathrm{TD}$ and $30 \% \mathrm{HS}$ tailings, respectively), and $\mathrm{Zn}\left(0.52\right.$ and $0.45 \mu \mathrm{g} \mathrm{ml}^{-1} \mathrm{Zn}$ in extracts of $30 \%$ TD and $30 \%$ HS tailings, respectively) than the other tailings samples.

Germination percentages of $B$. chinensis and $C$. dactylon seeds treated with different tailings/soil extracts
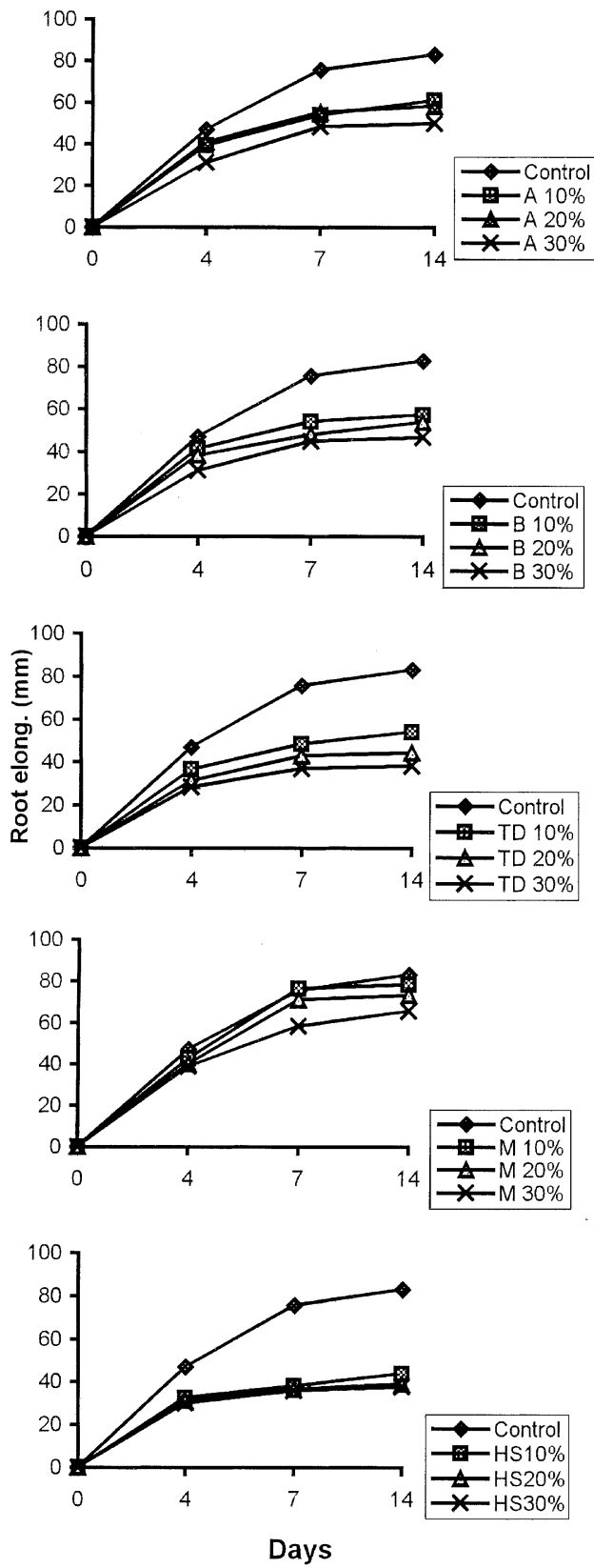

B. chinensis were recorded at days 4, 7 and 14 (data not presented here). The results showed that there were no significant differences in germination rate among the different treatments for both species. Similar results were reported when seeds of Agropyron elongatum and Trifolium repens were germinated in the $\mathrm{Pb} / \mathrm{Zn}$ tailings
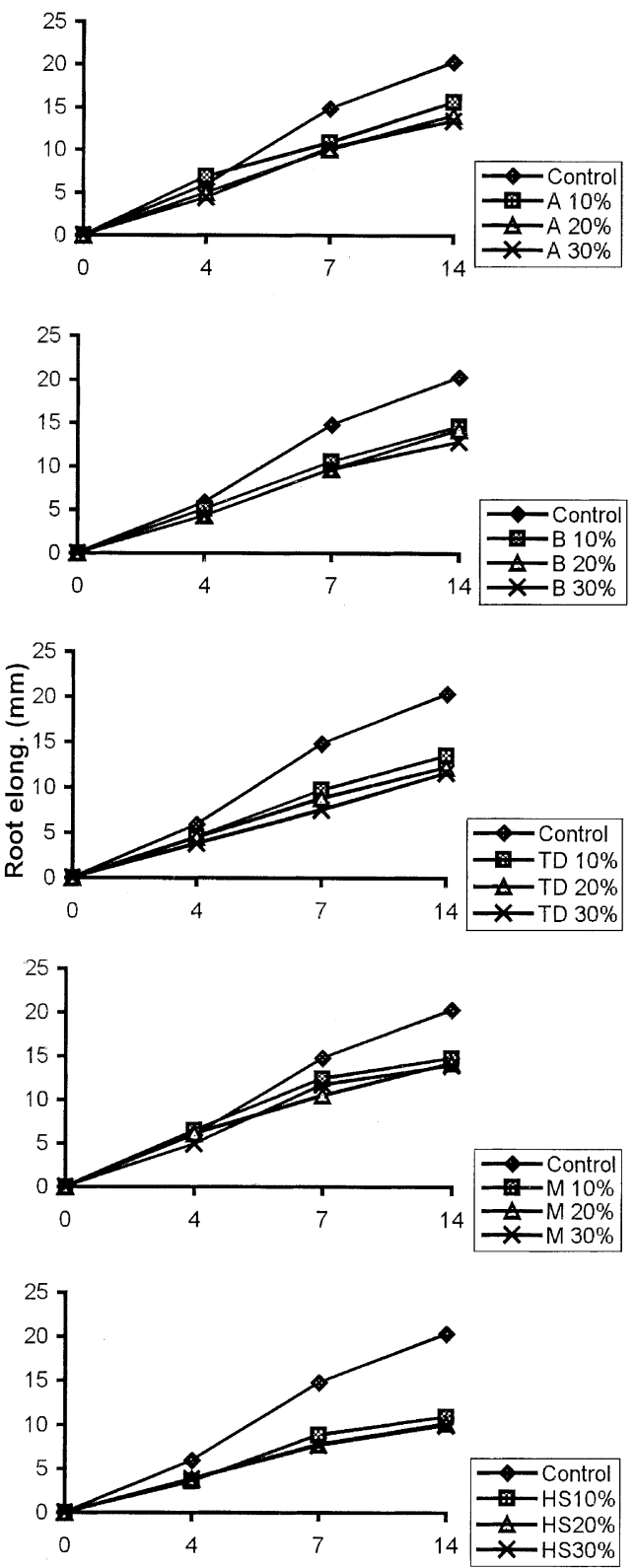

Days

C. dactylon

Fig. 1. Root elongation $(n=40)$ of $B$. chinensis and $C$. dactylon in extract of different tailings and soils. Control: distilled water. Percentages indicate concentrations of the extracts (w/v). A: densely vegetated tailings, B: sparsely vegetated tailings, TD: tailings heap, M: mountain site, and HS: high-sulfur tailings. 
amended with different amounts of lime and fertilizer (Ye et al., 1999).

Comparison of root elongation of $B$. chinensis and $C$. dactylon grown in different concentrations of the extracts of the tailings and soils showed that $B$. chinensis had a longer root length than $C$. dactylon (Fig. 1). It was apparent that $B$. chinensis was more sensitive to metal toxicity in the extracts than $C$. dactylon. Drastic inhibition of root elongation of $B$. chinensis was observed in extracts $(10 \%, 20 \%$, and $30 \%)$ of HS tailings. In the same plant, root elongation in extracts of the mountain soil was similar to OF soil (control), indicating the soil at Site $\mathrm{M}$ was not toxic to $B$. chinensis. The toxicity ranking of extracts for $B$. chinensis was: high-sulfur tailings (HS) $>$ tailings heap (TD) $>$ sparsely vegetated tailings (B) $>$ densely vegetated tailings (A) $>$ mountain soil (M). A similar trend was also observed for C. dactylon (Fig. 1).

Table 3 shows the root length of plants given in Fig. 1, expressed as $\mathrm{ECG}_{30}$. The results confirmed that the rankings of toxicity for both $B$. chinensis and $C$. dactylon were similar to toxicity ranking of the extracts mentioned above.

\subsubsection{Seedling growth test}

The mixtures of different ratios of farm soil (OF) with the tailings resulted in changes of texture, decreases of $\mathrm{pH}, \mathrm{EC}$, and metal concentrations (data not presented here). In general, concentrations of total and extractable metals $(\mathrm{Pb}, \mathrm{Zn}, \mathrm{Cd}$ and $\mathrm{Cu})$ in the mixtures were significantly reduced after mixing with $50 \%$ and above $50 \%$ farm soil in the tailings. The decrease of $\mathrm{pH}$ in the mixtures was due to acidic nature of the farm soil, whereas the decrease of EC and metal contents was due to dilution effects.

Plant growth data (Fig. 2) show that in the unamended tailings, total dry weight yield of $B$. chinensis was the highest when grown in Site A tailings, followed by Sites B, TD, and HS tailings (Fig. 2). Fig. 2 also shows that total dry weight yield of $B$. chinensis was signifi-

Table 3

$\mathrm{ECG}_{30}$ of tailings and soil extracts $(\%)$ on root elongation of Brassica chinensis and Cynodon dactylon

\begin{tabular}{llllllll}
\hline & \multicolumn{3}{l}{ B. chinensis } & & & \multicolumn{3}{c}{ C. dactylon } \\
\cline { 2 - 3 } \cline { 6 - 8 } & Day 4 & Day 7 & Day 14 & & Day 4 & Day 7 & Day 14 \\
\hline A & 28.7 & 24.7 & 19.9 & & NR & 15.6 & 18.7 \\
B & 28.5 & 15.0 & 9.69 & & NR & 18.5 & 16.2 \\
TD & 17.6 & 8.13 & 9.09 & & 26.4 & 9.09 & 9.70 \\
M & NR & NR & NR & & NR & NR & NR \\
HS & 9.68 & 6.25 & 6.88 & & 8.13 & 7.50 & 6.56 \\
\hline
\end{tabular}

A: densely vegetated tailings, B: sparsely vegetated tailings, TD: tailing heap, M: mountain site, HS: high-sulfur tailings, NR: no reduction. cantly increased when grown in Site A tailings, mixed with $50 \%$ and above $50 \%$ farm soil. However, $50 \%$ farm soil did not significantly increase total dry weight yields of B. chinensis when grown in Sites B, TD and HS tailings. These results suggest tailings collected from Site A are less toxic than other tailings, which is similar to the results from the root elongation toxicity test.
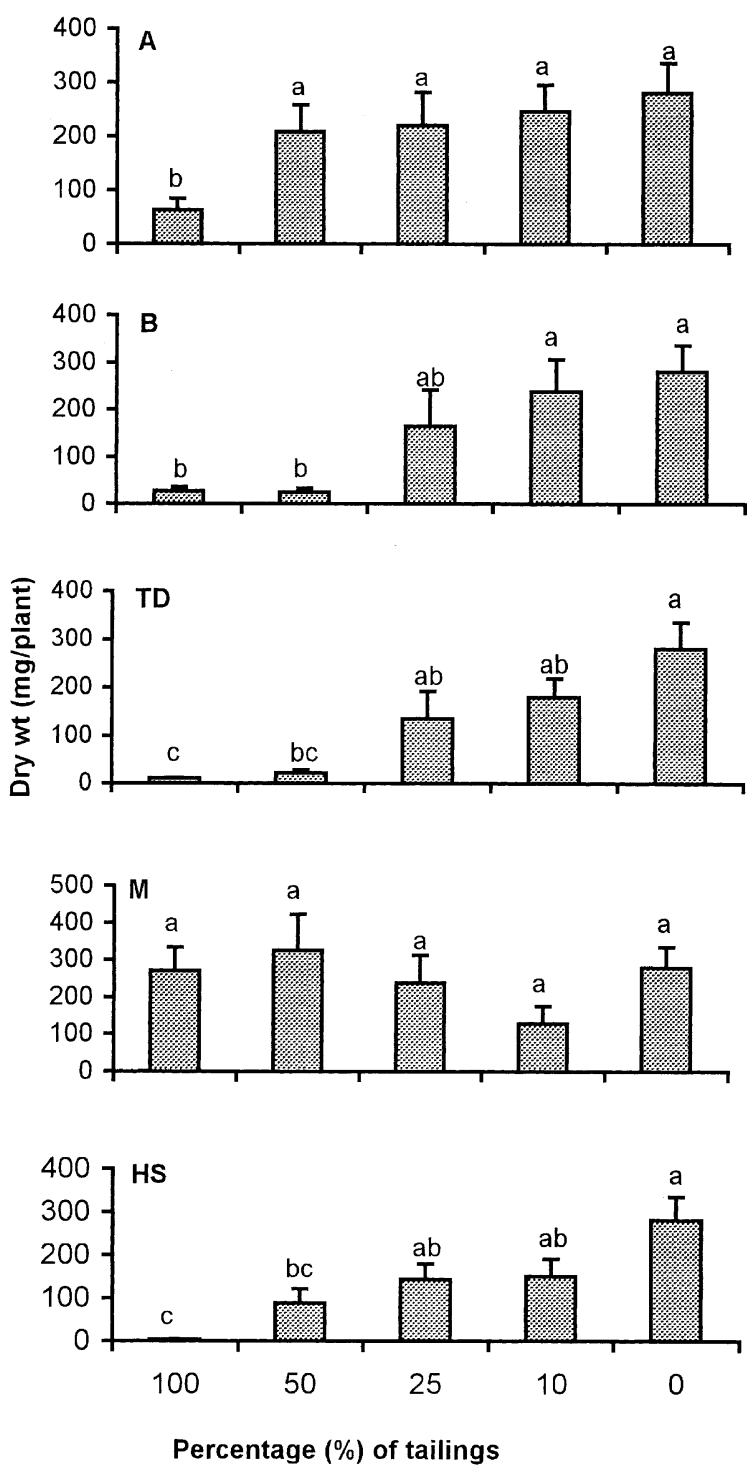

Fig. 2. Dry weights (mg/plant) of $B$. chinensis seedlings grown in different tailings/soil substrata amended with agricultural soil (AS) for a period of 4 weeks (mean \pm s.e., $n=9)$. (100: $100 \%$ tailings, 50: 50\% tailings $+50 \%$ AS, 25: $25 \%$ tailings $+75 \%$ AS, 10: $10 \%$ tailings $+90 \%$ AS, 0: $100 \%$ AS, w/w). Different letters in the same figure indicate significant difference at $p<0.05$ according to Tukey-HSD test. A: densely vegetated tailings, B: sparsely vegetated tailings, TD: tailings heap, M: mountain site, and HS: high-sulfur tailings. 
3.3. Relationship between tailings properties, metal concentrations and growth responses

The results of total and DTPA-extractable metal contents in tailings, root elongation, $\mathrm{ECG}_{30}$ of root elongation and total dry weight yield of seedlings (Tables 2 and 3, Figs. 1 and 2) show that extractable $\mathrm{Pb}$ contents of the tailings appear to be related to the toxic effects of the tailings. The extractable $\mathrm{Pb}$ contents in the tailings are in the descending order: Site $\mathrm{SH}\left(178 \mu \mathrm{gg}^{-1} \mathrm{~Pb}\right)>$ Site TD $\left(112 \mu \mathrm{gg}^{-1} \mathrm{~Pb}\right)>$ Site B $\left(85 \mu \mathrm{gg}^{-1} \mathrm{~Pb}\right)>$ Site $\mathrm{A}\left(59 \mu \mathrm{gg}^{-1} \mathrm{~Pb}\right)$, while the results of root elongation, expressed as $\mathrm{ECG}_{30}$, and dry weights yields of $B$. chinesis were in the opposite order. The results for $\mathrm{Zn}$ do not show such a clear relationship. It is commonly known that $\mathrm{Pb}$ does not play any essential role in plant metabolism and is toxic to plants. According to Ross (1994) the toxicity of metals in higher plants is $\mathrm{Hg}>\mathrm{Pb}>\mathrm{Cu}>\mathrm{Cd}>\mathrm{Cr}>\mathrm{Ni}>\mathrm{Zn}$. Furthermore, concentrations of $\mathrm{Pb}$ in soil from $100-400$ $\mu \mathrm{gg}^{-1}$ were considered toxic by Kabata-Pendias and Pendias (1985). Zinc is an essential element for plant growth and its toxicity is less than $\mathrm{Pb}$.

When the tailings were mixed with farm soil, the greater the proportions of farm soil in the mixture, the greater were the total plant dry weight yields. This could be due to a reduction in toxicity or improvement in nutrient availability or in soil physical properties. Amendment with soil can clearly ameliorate the phytotoxic properties of tailings.

\section{Conclusions}

The results of the present study suggest that constraints to plant growth on tailings from $\mathrm{Pb} / \mathrm{Zn}$ mines can readily be quantified. At Lechang, high concentrations of $\mathrm{Pb}$ appear to restrict plant growth, characterized by the content of DTPA-extractable $\mathrm{Pb}$. However, salinity may also be a problem, together with the lack of $\mathrm{P}$ and N. The silty and sandy texture of tailings and the lack of organic matter is also likely to restrict root growth and impose susceptibility to wind and water erosion. Amendment of soil can reduce the toxicity of tailings and could be used for reclamation practice. This investigation was, however, based on samples from five different sites. It now needs to be refined by work using a wider range of materials.

\section{Acknowledgements}

The authors would like to thank the Lechang Lead/ Zinc Mine Company for supplying tailings materials and Professor A. D. Bradshaw of the School of Biological Sciences, University of Livepool, for his invalu- able comments. Financial support from the Research Grant Council of University Grants Committee, Hong Kong (HKBC117/94M) and Chinese Natural Science Fund (no. 39770154) is gratefully acknowledged.

\section{References}

Allen, S.E., Grimshaw, H.M., Parkinson, H.M., Quarmby, J.A., 1974. Chemical Analysis of Ecological Materials. Blackwell, Oxford.

Baker, D.E., Amacher, M.C., 1982. Nickel, copper, zinc, and cadmium. In: Page, A.L., Miller, R.H., Keeney, D.R. (Eds.), Methods of Soil Analysis. Part 2. Chemical and Microbiological Properties. Agronomy, No. 9. American Society of Agronomy and Soil Science Society of America, Madison, Wisconsin, pp. 323-336.

Bradshaw, A.D., Johnson, M., 1992. Revegetation of Metalliferous Mine Waste: The Range of Practical Techniques Used in Western Europe. Elsevier, Manchester.

Day, A.D., Ludeke, K.L., 1979. Disturbed land reclamation in an arid environment. In: Argall Jr., G.O. (Ed.), Tailings Disposal Today, vol. 2. Miller Freeman Publications, Inc., San Francisco, California, pp. 437-460.

DeKock, P.C., 1956. Heavy metal toxicity and iron chlorosis. Annals of Botany 20, 134-141.

Ernst, W.H.O., 1988. Response of plant and vegetation to mine tailings and dredged materials. In: Salomons, W., Forstner, U. (Eds.), Chemistry and Biology of Solid Waste Dredged Material and Mine Tailings. Springer-Verlag, New York, pp. 54-69.

Freedman, B., 1995. Environmental Ecology-Tthe Ecological Effects of Pollution Disturbance and Other Stresses. Academic Press, London.

Greenway, H., Munnus, R., 1980. Mechanisms of salt tolerance in nonhalophytes. Annual Review Plant Physiology 31, 149-169.

Godbold, D.L., 1994. Aluminum and heavy metal stress: from the rhizosphere to whole plant. In: Godbold, D.L., Huttermann, A. (Eds.), Effects of Acid Rain on Forest Processes. Wiley-Liss, New York, pp. 231-264.

Grimshaw, H.M., 1989. Analysis of soil. In: Allen, S.E. (Ed.), Chemical Analysis of Ecological Materials. Blackwell, Oxford, pp. 7-45.

Hewitt, E.J., 1966. Sand and Water Culture Methods Used in the Study of Plant Nutrition. Commonwealth Agricultural Bureaux, Slough.

Johnson, M.S., Cooke, J.A., Stevenson, J.K.W., 1994. Revegetation of metalliferous wastes and land after metal mining. In: Hester, R.E., Harrison, R.M. (Eds.), Mining and its Environmental Impact. Issues in Environmental Science and Technology, Royal Society of Chemistry, London, pp. $31-48$.

Kabata-Pendias, A., Pendias, H., 1985. Trace Elements in Soils and Plants. CRC Press, Boca Raton.

Lindsay, W.L., Norvell, W.A., 1978. Development of a DTPA test for zinc, iron, manganese, and copper. Soil Science Society of America Journal 42, 421-428.

Little, T.M., Hills, J.J., 1978. Agricultural Experimentation: Design and Analysis. John Wiley \& Sons, Chichester. 
Nielson, R.A., Peterson, H.B., 1972. Treatment of Mine Tailings to Promote Vegetative Stabilisation. Agricultural Experiment Station, Logan, Utah, Bulletin 485.

Olsen, S.R., Sommers, L.E., 1982. Phosphorus. In: Page, A.L., Miller, R.H., Keeney, D.R. (Eds.), Methods of Soil Analysis. Part 2. Chemical and Microbiological Properties. Agronomy, No. 9. American Society of Agronomy and Soil Science Society of America, Madison, Wisconsin, pp. 403430.

Pichtel, J.R., Dick, W.A., Sutton, P., 1994. Comparison of amendments and management practices for long-term reclamation of abandoned mine lands. Journal of Environmental Quality 23, 766-772.

Ross, S.M., 1994. Toxic Metals in Soil-plant Systems. John Wiley \& Sons, Chichester.

Sidle, R.C., Chambers, J.C., Amacher, M.C., 1991. Fate of heavy metals in an abandoned lead-zinc tailings pond: II. Sediment. Journal of Environmental Quality 20, 752-758.

Smith, B.M., 1991. An inter- and intra-agency survey of the use of plants for toxicity assessment. In: Gorsuch, J.W., Lower, W.R., Wang, W., Lewis, M.A. (Eds.), Plants for Toxicity Assessment, vol. 2. American Society for Testing and Materials, Philadelphia, pp. 41-59.

Shu, W.S., 1997. Revegetation of Lead/Zinc Mine Tailings. Ph.D. Thesis, Zhongshan University, Guangzhou, P.R. China.

Smith, R.A.H., Bradshaw, A.D., 1979. The use of metal tolerant plant populations for the reclamation of metalliferous wastes. Journal of Applied Ecology 16, 595-612.
USEPA, 1992. Seed germination/root elongation toxicity test. EG-12, Office of Toxic Substances, U.S. Environmental Protection Agency, Washington, DC.

Wild, A., 1988. Soil Conditions and Plant Growth, 11th ed. The Bath Press, Avon.

Wild, A., 1993. Soil and the Environment: An Introduction. Cambridge University Press, Cambridge.

Wong, M.H., Bradshaw, A.D., 1982. A comparison of the toxicity of heavy metals using root elongation of ryegrass, Lolium perenne. New Phytologist 91, 255-261.

Wong, M.H., Lau, W.M., 1983. Effects of roadside soil extracts on seed germination and root elongation of edible crops. Environment Pollution 31, 203-215.

Woolhouse, H.W., 1983. Toxicity and tolerance in responses of plants to metals. In: Lange, O.L., Nobel, P.S., Osmond, C.B., Ziegler, H. (Eds.), Encyclopedia of Plant Physiology. New Series, vol. 12C. Springer-Verlag, Berlin, pp. 245-300.

Ye, Z.H., Wong, J.W.C., Wong, M.H., Lan, C.Y., Baker, A.J.M., 1999. Lime and pig manure as ameliorants for revegetating lead/zinc mine tailings: a greenhouse study. Bioresource Technology 69, 35-43.

Ye, Z.H., Wong, J.W.C., Wong, M.H., Baker, A.J.M., Shu, W.S., Lan, C.Y., 2000. Revegetation of $\mathrm{Pb} / \mathrm{Zn}$ mine tailings, Guangdong province, China. Restoration Ecology 8, 87-92.

Young, K., 1988. Destruction of ecological habitats by mining activities. Agricultural Ecology 16, 37-40.

Zhijiang Agricultural University, 1991. Plant Nutrition and Fertilizer. Agricultural Press, Beijing. 